\title{
7. 肝硬変における肝以外の臟器の障害
}

\section{佐藤 信紘* 駒田 敏之**}

要旨

肝硬变では, 胸腹腔内血管シャントの存在や血管調節因子の変動による特殊な血行動態異常 が存在することにより，肝以外の重要臓器の有効循環血液量の減少を主因とする様々な合併症 を併発し，多臓器不全に宿りやすい条件下にある。肝硬变患者を診療する際には肝病変だけで なく, 消化管, 腎臓, 造血器, 呼吸器, 循環器等の肝以外の臟器障害の発生機序と対策につい ても理解し，全身的な管理に勤めることが重要である。

[日内会誌 $80 ： 1605 \sim 1610 ， 1991]$

Key words: 肝硬变, 血行動態異常, 蔵器障害, 多臓器不全

\section{はじめに}

近年, 肝硬変に括ける食道静脈瘤や肝性脳症, 腹水，肝癌などの合併症に対する診断技術や治療 法の進歩に伴い，日本における肝硬变患者の生存 期間は漸次延長してきている。

これらの合併症を防止しつつ，肝硬変患者を長 期間にわたり経過観察していると，特に非代償性 肝硬変や末期の肝硬変では，軽微な消化管出血や 感染症を契機として，腎不全や呼吸不全など肝以 外の藏器の障害をきたし，いわゆる多臓器不全の 様相を呈し死に至ることも多い，本稿では，肝硬 変に括いて多発する肝以外の臓器の障害, 特に食 道静脈瘤以外の消化管病変, 腎障害, 造血器障害, 呼吸・㡒環器障害を中心と乙て，その成因と対策 について述べる。

\section{1. 消化管の障害}

\section{1）上部消化管病変の発生頻度}

肝硬変患者に胃十二指腸粘膜病変が高頻度に合 併することは古くから知られている。肝硬变に合

*さとらのら゙ひろ，**こまだ としゅき，順天堂 大学消化器内科
併する胃十二指腸病変の頻度は，急性胃粘膜病変 (AGML)が20３0\%，胃十二指腸潰瘍が $15 ２ 0 \%$ と報告されている。現在，肝硬変の死因の約 $30 \%$ 消化管出血が占めているが，その出血部位とし て，食道静脈瘤からの出血についで胃十二指腸粘 膜病变からの出血が多い（表 1 ）。

したがって，肝硬変に合併する胃十二指腸粘膜 病変の発生機序を解明して，病態を把握し，対策 を構じることは，肝硬変患者を診療する上で極め て重要である。

表 1. 食道静脈瘤を伴う肝硬変患者の消化管出血源

\begin{tabular}{|c|c|c|c|}
\hline \multirow[t]{2}{*}{ 出 血 源 } & Bonannt 5 & Terés 5 & 房 本 \\
\hline & $\begin{array}{l}\text { 症例数 } \\
(\%)\end{array}$ & $\begin{array}{l}\text { 症例数 } \\
(\%)\end{array}$ & $\begin{array}{c}\text { 症例数 } \\
(\%)\end{array}$ \\
\hline 食道・胃静脈瘤 & $33(42.8)$ & $91(47.1)$ & $26(65.0)$ \\
\hline 急性粘膜病変 & $29(37.7)$ & $43(22.3)$ & $3(7.5)$ \\
\hline 胃 - 十二指腸漬瘍 & $7(9.1)$ & $26(13.5)$ & $10(25.0)$ \\
\hline 多発出血源 & 0 & $20(10.4)$ & 0 \\
\hline $\begin{array}{l}\text { Mallory-Weiss } \\
\text { 症候群 }\end{array}$ & $8(10.4)$ & 0 & 0 \\
\hline \multirow{3}{*}{$\begin{array}{lll}\text { 艺 } & \text { 他 } \\
\text { 不 } & & \text { 明 }\end{array}$} & 0 & $2(1.0)$ & $1(2.5)$ \\
\hline & 0 & $11(5.7)$ & 0 \\
\hline & $77(100.0)$ & $193(100.0)$ & $40(100.0)$ \\
\hline
\end{tabular}


表 2. 肝硬変患者と健常人に抢ける胃粘膜血液量の分布㧍よび粘膜内血液の酸素化度

a 、胃粘膜血液量 $(\Delta \mathrm{Er})$ の分布

\begin{tabular}{c|c|c|c|c|c}
\hline \multicolumn{1}{c|}{$\operatorname{Er}(\mathrm{OD})$} & Antrum & Angle & L. Corpus & M. Corpus & U. Corpus \\
\hline Control $(\mathrm{n}=45)$ & & & & & \\
Lesser curvature & $0.55 \pm 0.11$ & $0.60 \pm 0.10$ & $0.65 \pm 0.11$ & $0.67 \pm 0.12$ & $0.68 \pm 0.10$ \\
Greater curvature & $0.63 \pm 0.12$ & $0.68 \pm 0.10$ & $0.72 \pm 0.11$ & $0.72 \pm 0.13$ & $0.74 \pm 0.13$ \\
\hline Liver cirrhosis $(\mathrm{n}=46)$ & & & & & \\
Lesser curvature & $0.60 \pm 0.15$ & $0.65 \pm 0.15$ & $0.73 \pm 0.13^{*}$ & $0.72 \pm 0.14$ & $0.73 \pm 0.14$ \\
Greater curvature & $0.68 \pm 0.13$ & $0.73 \pm 0.14$ & $0.77 \pm 0.16$ & $0.77 \pm 0.16$ & $0.77 \pm 0.16$ \\
\hline
\end{tabular}

Results are expressed as Mean \pm S.D.

*; Significantly different from the control

b. 粘膜内血液酸素化度 $\left(\mathrm{ISO}_{2}\right)$

\begin{tabular}{c|c|c|c|c|c}
\hline $\mathrm{ISO}_{2}(\% \times 1 / 100)$ & Antrum & Angle & L. Corpus & M. Corpus & U. Corpus \\
\hline Control $(\mathrm{n}=45)$ & & & & & \\
$\quad$ Lesser curvature & $0.61 \pm 0.10$ & $0.64 \pm 0.08$ & $0.63 \pm 0.07$ & $0.62 \pm 0.07$ & $0.63 \pm 0.09$ \\
Greater curvature & $0.63 \pm 0.11$ & $0.63 \pm 0.08$ & $0.60 \pm 0.06$ & $0.60 \pm 0.08$ & $0.60 \pm 0.07$ \\
\hline Liver cirrhosis $(\mathrm{n}=46)$ & & & & & \\
Lesser curvature & $0.58 \pm 0.09$ & $0.57 \pm 0.09^{*}$ & $0.58 \pm 0.09^{*}$ & $0.57 \pm 0.07^{*}$ & $0.57 \pm 0.07^{*}$ \\
Greater curvature & $0.60 \pm 0.09$ & $0.57 \pm 0.09^{*}$ & $0.56 \pm 0.08^{*}$ & $0.55 \pm 0.09^{*}$ & $0.55 \pm 0.08^{*}$ \\
\hline
\end{tabular}

Results are expressed as Mean士S.D.

[文献 2)上り引用]

*; Significantly different from the control

\section{2）胃十二指腸粘膜病变の発生機序}

\section{（1）胃粘膜防御機構（防御因子）の変化}

胃酸，ペプシンなどの攻撃因子から胃粘膜を防 御する機構としては，(1)粘膜上皮を被覆し，逆透 過する酸を中和する場として重要な粘液，(2)粘膜 上皮より分泌され，逆透過する酸の中和に役立つ 重炭酸イオン，(3)粘膜上皮に結合して蹯水性のバ リアーを形成するリン脂質，(4)粘膜の修復にあた る細胞回転などがありこれいは胃粘膜血流によ り維持されており，またプロスタグランディン （PG)などによって調節を受けている。粘液执よび 重炭酸イオンの表層粘膜上皮からの分泌には

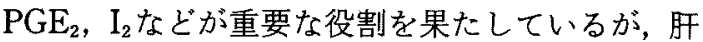
硬変では，胃粘膜内 $\mathrm{PGE}_{2}$ が低下していることが 指摘されている。

また，臓器反射スペクトル解析法を用いて胃粘 膜血液量と粘膜内血液の酸素化度を測定すると， 肝硬変症患者の胃粘膜血液量は健常者に比べて約 10 数\%多く，粘膜内酸素化度は約 $5 \%$ 低く，その 程度は前庭部では軽く, 胃角部や胃体部に強い傾 向にあった（表 $2 a ， b)$ ．むた，食道静脈瘤を有す
る肝硬変患者では，静脈瘤を有さない群に比べて 粘膜内の酸素化度は更に低下していた22，胃粘膜 血液量が増加し粘膜内酸素化度が低下すること は，胃粘膜の毛細血管の抎張と血流のうっ滞に伴 ら胃粘膜酸素需給の悪化を示している。

肝硬变の胃粘膜は, 門脈圧上昇の結果潅流障害 を引き起こして胃上部を中心にしてうっ血状態に あり, 胃粘膜表層の粘膜上皮細胞は常に低酸素, 低栄養の状態にさらされ，このことが胃粘膜防御 機構の減弱を引き起こし, 粘膜病变発生の一因に なっている，また，十二指腸粘膜でも胃粘膜と同 様の機序で粘膜防御機構が減弱していることが示 されている，さらに，肝硬変に伴う蛋白および脂 質の合成障害による低栄養もこの胃十二指腸粘膜 防御機構の破綻を助長していると考えられる。

\section{（2）攻撃因子の変化}

肝硬变においては，血中ガストリン值は正常も しくは高值であるが，胃底腺の萎縮性変化が進行 して扣り，攻撃因子である胃酸やぺプシンの分泌 は低下しているとの報告が多い。

しかし，潰瘍合併例では低酸例は少なく正酸あ 
るいは過酸例が多いといら特徵があり，潰瘍につ いては胃液分泌の関与む大きいことを示してい る.特に重症例では苦痛に伴らストレスが加わり, 粘膜防御機構の障害も強いため容易に胃十二指腸 病変を発症しゃすい.

\section{(3) 胆汁酸の関与}

肝硬変では胃十二指腸の運動障害により，胃内 に胆汁の逆流をきたしやすく，胃排出機能子悪い ので逆流した胆汁は胃内にらっ滞しやすい，肝硬 変ではタウロコール酸などの胆汁酸に対する胃粘 膜抵抗の減弱がみられるとの報告や，血中に増加 した胆汁酸が胃粘液の分泌を低下させ胃粘膜防御 機構を障害することが知られており，胃内に逆流 した胆汁酸によっても胃十二指腸粘膜病変が容易 に惹起されると思われる。

\section{（4）肝動脈塞栓衍（TAE）後の上部消化管病変}

肝癌合併肝硬变ではTAE後に潰瘍や出血性び らんなどの胃十二指腸粘膜病变をきたすことがあ る。この発生原因としては，塞栓物質の胃支配血 管への流入による虚血や抗癌薬の流入による胃粘 膜の再生障害などの他，治療に伴らストレスも関 与していると思われる。

\section{3）上部消化管病変に対する対策}

肝硬変に拈ける胃十二指腸粘膜病変に対する対 策は，その発症機序から考えると，まず胃粘膜微 小循環を含めた胃粘膜防御機構の改善执よび増強 を主体とすべきである。防御因子増強薬としては， 胃粘膜保護薬や内因性PG合成促進薬あるいはPG 誘導体などが有効と思われる，さらに，粘膜防御 機構の減弱のため, 少量の酸で粘膜病変が発生し やすくなって打り， $\mathrm{H}_{2}$ 受容体拮抗薬やムスカリン 受容体拮抗薬の投与が大切である.

潰湟合併例では正酸もしくは過酸例が多く, 胃 液分泌の抑制が必要であるが，ヒスタミン $\mathrm{H}_{2}$ 受容 体拮抗薬やプロトンポンプ阻害薬が有効である。 その他胃十二指腸運動障害の改善を目的として， 消化管運動機能改善薬の併用も考慮すべきであ る。

潰瘍出血に対してはェタノール局注などの内視 鏡的止血療法が有効である。

\section{4）その他の消化管病変}

門脈圧亢進が進行すると，下部消化管粘膜血流 のうっ滞をきたし, 腸間膜静脈瘤や大腸の静脈瘤, 潰瘍あるいは出血性びらんを合併することがあ る。著者らも重症肝硬変に大腸潰瘍と出血性びら んを合併し下血を頻回にきたしたが，内視鏡的エ タノール散布が有効であった例を経験している。

\section{2. 腎障害}

1) 肝腎症候群 (hepatorenal syndrome)

肝硬変で死亡する症例の50 75\%に腎不全が認 められるが，肝硬変にみられる腎不全は，病理組 織学的所見に異常を認めない機能性腎不全と，急 性尿細胞壊死の病理所見を呈する虚血性腎不全に 大別される，悠密には非代償期の肝硬変に合併す る機能性腎不全を特に肝腎症候群と呼ぶが，機能 性腎不全から急性尿細管壊死へ移行する症例子多 く, 臨床的には機能性腎不全（肝腎症候群）と急 性尿細管壊死を明確に区別するのは困難なことが 多いので両者を一括して述べる。

肝腎症候群の成因としては，腎皮質血管の弯縮 による腎内血流分布の変化を主体とする腎血流量 の低下が考光られている，代償性肝硬変の糸球体 沪過值 (GFR) と腎血㓡流量 (RPF) は正常加軽 度の低下を示す程度であるが，腎内血流分布の異 常はこの頃からすでに認められ，非代償期では腎 内血流分布の不均衝はさらに強くなり，GFR, RPFは正常值の50\%以下に低下するといわれて いる.以下, Papper ${ }^{31} の$ 仮説に基づいて肝硬変に括 ける腎不全の発生機序について述べる（図 1 ). 非代償性肝硬变では腹腔内臟器血管のシャント の存在や腹水貯留による腎外血流分布異常があ り，有効腎血流量が減少するため，交感神経の緊 張六進が生じ，またレニン・アンギオテンシン・ アルドステロン系の活性化を引き起こすことによ り輸入動脈の孪縮をきたす。

一方，肝硬変では，カリクレインやブラディキ ニンなどの血管拡張性因子の合成低下があり， フェニルェタノールアミンなどの血管作動性の弱 い偽性神経伝達物質が肝で分解されず蓄積される 


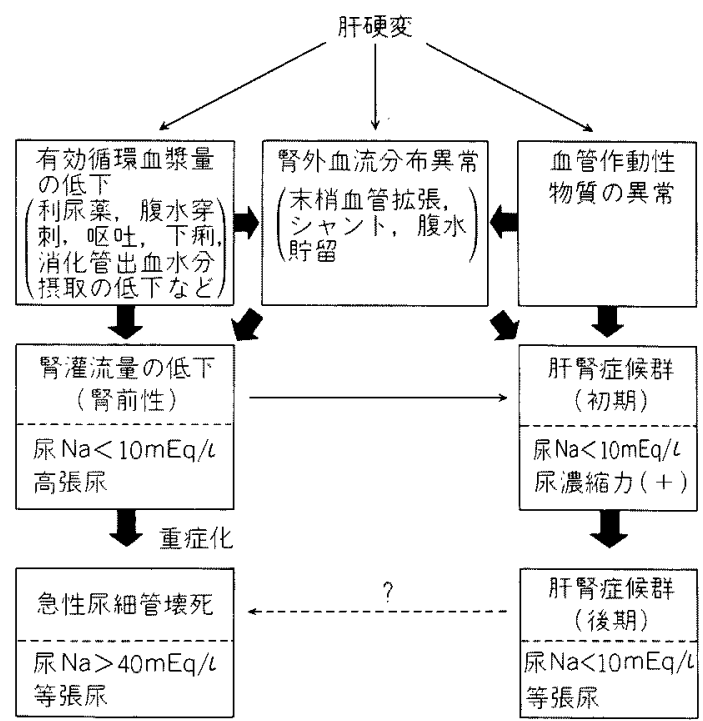

(文献3)より引用，一部改变)

図 1.肝硬変に打ける腎不全の発生機序

ため，腎内血流分布異常や短絡をきたすと考えら れる. 腎血流は交感神経, カテュラミン系, レニ ン・アンギオテンシン・アルドステロン系, カリ クレイン・キニン系, $\mathrm{PG}$ 系やエンドテリンなどの 血管収縮因子と拡張因子の相互関係が均衡を保つ ことにより維持されているが，肝硬変では，これ ら血管調節因子の増減があり，均衡が崩れやすい と考壳られる。

さらに，非代償性肝硬变では，利尿薬の使用， 腹水穿刺, 下浰, 消化管出血に伴い, 有効循環血 液量の減少，腎血流量の減少をきたし，腎前性の 腎不全に陥ることがある。この場合は虚血性変化 を伴う急性尿細管壊死の像を呈することがしばし ばある。

その他, 消化管のグラム陰性菌に由来するエン ドトキシンは門脈系を介して肝網内系で不活化さ れるが, 重症の肝硬変では網内系機能の低下や門 脈・大循環系のシャントのために，エンドトキシ ン血症を起こしやすく，エントトキシンには強力 な腎血管収縮作用があるため腎血流量の低下をき たす。さらに,エンドトキシンによりDICを惹起さ れると糸球体および尿細管周囲血管に血栓を形成 し，強い尿細管壊死が起こる。
肝硬变において腎血行動態異常に変化をおよぼ 寸要因について挙げると，以上述べたように，(1) 有効循環血液量の減少, (2)腎外循環血流分布の変 化に対する腎血管の反応性挛縮, (3)血管作動性因 子の関与, (4)エンドトキシン血症の関与がある. 肝硬変では，これらの要因が絡みあって腎機能障 害を来すと考劣られる。

2) 肝性系球体硬化症 (hepatic glomerulosclerosis)

肝腎症候群が腎の機能的障害であるのに対し， 肝硬変ではしばしば糸球体病変を合併することが 知られている。

血尿と蛋白尿を伴う腎炎性尿所見は肝硬変患者 の約10\%弱にみられ，1〜2\%にネフローゼ症候 群を合併すると報告されており，異常尿所見の出 現頻度は高くはないが, 組織学的検査では肝硬变 剖検腎の $50 \%$ 以上に糸球体病変が観察される。こ の系球体病変は肝性系球体硬化症とよばれ，その 成因としては，IgA腎症のようなimmune com plex diseaseとしての糸球体腎炎と考えられてい る、肝硬变で高頻度に認められる糸球体沈着物は $\operatorname{IgA}$ 免疫複合体であり，特にアルコール性肝硬変

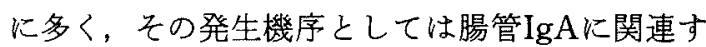
るcirculating immune complexが門脈・大循環系 のシャントを介して大循環に取り込をれ，系球体 に沈着すると想定されている，その他，HBs抗原 やHBe抗原などの旰炎ウイルスを抗原とする免 疫複合体が系球体メサンギウム部に沈着して起こ る糸球体腎炎も多く報告されて扣り，いずれも膜 性腎症, 膜性增殖性系球体腎炎や時には急性進行 性系球体腎炎の病像を呈する。

\section{3）腎障害の対策}

肝腎症候群を合併すると予後は非常に亜くなる ので，その予防が重要である．肝腎症候群を予防 するためには, 感染や消化管出血の防止の他, 利 尿薬の使いすぎや腹水の大量除去を避け, 有効循 環血液量を減少させないような配慮が必要であ る.腹水のコントロールをする場合にはNa制限や アルブミン製剤の併用, 腹水濃縮再注入により腎 障害の発生防止に努める。

肝腎症候群を発症した場合には，有効循環血液 
量を最低限保持することが必要で, Na制限をした 上で補液，アルブミン製剤の投与を行ら。薬物療 法としては，ドーパミンが奏効を示したといら報 告があるが，PG製剤の投与や，腎血管挛縮の予防 を目的としたトロンボキサン $\mathrm{A}_{2}$ 阻害薬の使用な どを含めて今後の検討課題である。

肝性糸球体硬化症に対しては，一般の糸球体腎 资の治療と同様であるが, 非ステロイド系抗炎症 薬の投与により，PGの合成が抑制され，肝腎症候 群を誘発することがあるので注意を要する。

\section{3. 造血器の異常}

\section{1）赤血球の異常}

肝硬变患者の多くは負血を有しているが，その 成因として赤血球寿命の短縮と赤血球産生能の低 下が挙げられる. 肝硬変では赤血球膜成分の変化 や解糖系に異常がみられ, 脾機能の亢進も加わり, 約 $75 \%$ の例に赤血球寿命の短縮がみられる。 また 肝硬変患者の骨髄は過形成を示すことが多いが， 赤血球鉄利用率の低下や肝における葉酸の貯蔵力 の低下がみられ，赤血球産生能も障害されている と考えられる。

\section{2）白血球の異常}

白血球の異常としては, 脾藏でのプールの増大 の結果白血球数特にリンパ球数の減少が特徵的で ある、顆粒球数の減少すみられ，好中球自体の貪 食殺菌機能は健常人と比べて变化はないが，肝硬 変患者血清では好中球を遊走させる作用が低下し て扔り，易感染性の一因となっている可能性があ る.

\section{3）血小板の異常}

肝硬変に括ける血小板減少には脾腫大と静脈瘤 を含む血管系の異常による血小板プールの増大が 大きく関与している4．しかし，肝硬変患者の血小 板では, シアル酸量の低下や血小板膜のシアロ糖 蛋白の減少などがみられ，血小板自体の異常によ る血小板寿命の短縮も関与していると考支られ 万.

\section{4. 呼吸器 - 循環器障害}

\section{1）低酸素血症}

肝硬変の呼吸器合併症として低酸素血症が高率 に認められることが知られているが，その成因と しては，(1)肺内毛細血管の拡張と間質性肺水腫に よる換気血流比不均衡および肺払散障害, (2)肺動 静脈間あるいは門脈肺静脈間のシャントの存在, (3)へモグロビンの酸素親和性の低下，(4)肺胞低換 気などが挙げられる51.

\section{2) 肺高血圧症}

肝硬変では末梢動静脈シャントの増加, 循環血 液量の増大, 低酸素血症なと゚により，心拍出量は 増大し, hyperdynamic circulationの状態となっ ている，高心拍出状態が持続することにより肺血 管に二次的変化をきたし，肺高血圧を合併するこ とがある。

\section{3）循環器障害}

非代償性肝硬変では腹水の貯留により腹腔内圧 が上昇し，横隔膜が挙上することにより胸腔内圧 わ上昇するため, 静脈還流量が減少して心機能の 低下をきたす。また全身への酸素供給の増大を目 的とした高心拍出状態が続くと高拍出性心不全 きたすし，アルコール性肝硬変ではアルコール性 心筋症に上る心機能低下を合併することがある。

\section{4) 呼吸・循環器障害の対策}

肝硬变では全身および肺血行動態に括いて hyperdynamic stateが存在し, 換気血流比不均衡 やシャントによる低酸素血症をさたし，呼吸不全 や心不全に進展することがあるが，これらに対し 酸素吸入や循環改善薬であるドブタミンの投与は 心筋収縮能を高め，かつ肺血管系の抵抗を減少さ せるため有効と思われる。李た間質性肺水腫によ る換気血流比不均衡や拡散障害の改善を目的とし て，重症呼吸不全症例にメチルプレドニゾロンが 用いられることがある。

\section{おわりに}

以上述べたように肝硬変では，消化管出血，腎 
不全, 呼吸不全, 感染など重篤な合併症を来しゃ すい条件下にある。したがって肝硬变患者を管理 する際には，これらの合併症の発生機序と病態拉 よび対策を理解した上で, 肝以外の臓器の異常に も注目し，全身疾患として治療を行う必要がある。

$$
\text { 文献 }
$$

1）房本英之, 鎌田武信：上部消化管の緊急内視鏡検 查法. 消化器内視鏡マニュアル. 竹本忠良編, 改 訂第 2 版, 南江堂, 東京, $1989, \mathrm{p} 345$.
2）福田益樹, 他：肝硬変症患者の胃粘膜血行動態お よび酸素需給動態の検討。日消誌 $83: 26,1986$.

3) Papper $S$ : Renal failure in cirrhosis (the hepatorenal syndrome). Epstein M, ed, The Kidney in Liver Disease, Elsevier, New York, 1979, p91.

4) 渡辺勇四郎, 他：肝硬変患者の脾腫と血小板回転。 肝臓 $30: 29,1989$.

5）鈴木潤一, 他：肝硬変の低酸素血症。呼吸と偱環 $39: 333,1991$. 